Article

\title{
Impacts of Accumulated Particulate Organic Matter on Oxygen Consumption and Organic Micro-Pollutant Elimination in Bank Filtration and Soil Aquifer Treatment
}

\author{
Josefine Filter, Martin Jekel and Aki Sebastian Ruhl * \\ Chair of Water Quality Control, Technische Universität Berlin, Berlin 10623, Germany; \\ josefine.filter@tu-berlin.de (J.F.); Martin.Jekel@tu-berlin.de (M.J.) \\ * Correspondence: aki.s.ruhl@tu-berlin.de; Tel.: +49-303-142-5493 \\ Academic Editor: Thilo Hofmann
}

Received: 29 March 2017; Accepted: 9 May 2017; Published: 16 May 2017

\begin{abstract}
Bank filtration (BF) and soil aquifer treatment (SAT) are efficient natural technologies in potable water reuse systems. The removal of many organic micro-pollutants (OMPs) depends on redox-conditions in the subsoil, especially on the availability of molecular oxygen. Due to microbial transformation of particulate and dissolved organic constituents, oxygen can be consumed within short flow distances and induce anoxic and anaerobic conditions. The effect of accumulated particulate organic carbon (POC) on the fate of OMPs in BF and SAT systems is not fully understood. Long-term column experiments with natural sediment cores from the bank of Lake Tegel and from a SAT basin were conducted to investigate the impact of accumulated POC on dissolved organic carbon (DOC) release, on oxygen consumption, on mobilization of iron and manganese, and on the elimination of the organic indicator OMPs. The cores were fed with aerated tap water spiked with OMPs to exclude external POC inputs. Complete oxygen consumption within the first infiltration decimeter in lake sediments caused mobilization of iron, manganese, and DOC. Redox-sensitive OMPs like diclofenac, sulfamethoxazole, formylaminoantipyrine, and gabapentin were eliminated by more than $50 \%$ in all sediment cores, but slightly higher residual concentrations were measured in effluents from lake sediments, indicating a negative impact of a high oxygen consumption on OMP removal.
\end{abstract}

Keywords: bank filtration; soil aquifer treatment; sediments; organic micro-pollutants; particulate organic matter; oxygen consumption

\section{Introduction}

Bank filtration (BF) is an established, sustainable, and relatively inexpensive treatment for the production of high quality water from rivers and lakes [1]. Water is filtered through sediments and a sandy soil passage by applying a hydraulic gradient. For soil aquifer treatment (SAT), an artificial infiltration basin (or an injection well) is typically used instead of natural surface waters. Both BF and SAT provide passive exposure to various processes such as adsorption, physico-chemical filtration, and biodegradation that eliminate pathogens and many organic micro-pollutants (OMPs) including pharmaceuticals, biocides, and industrial chemicals, among others [2-5]. OMPs are not fully retained by conventional wastewater treatment and thus persist in the water cycle in $\mu \mathrm{g} / \mathrm{L}$ or $\mathrm{ng} / \mathrm{L}$ concentrations.

Removals of $80-90 \%$ were reported for the antibiotic sulfamethoxazole and the analgesic diclofenac in BF studies [4,5]. However, some OMPs such as the anti-corrosion agent benzotriazole or the anti-epileptic carbamazepine are not fully removed during BF [6,7]. Scheurer et al. [8] reported that the artificial sweeteners acesulfame and sucralose were persistent in monitored SAT basins. 
Diclofenac and other OMPs such as caffeine, ibuprofen, ketoprofen, naproxen, and gemfibrozil were efficiently removed during SAT within retention times of less than six months [9]. Bertelkamp et al. [10] investigated the sorption and biodegradation behavior of 14 OMPs in soil columns under oxic conditions and found that the presence of ethers and carbonyl groups increase biodegradability while amines and ring structures, aliphatic ethers, and sulfur impede degradation.

Besides the molecule structure, redox conditions determine the removals of some OMPs. Sulfamethoxazole was found in field studies to be better degraded under anoxic conditions (absence of oxygen) [2,4]. Diclofenac and formylaminoantipyrine were reported to be better degraded under oxic conditions [5,11]. The specific redox conditions are mainly determined by microbial processes [3]. Dissolved oxygen in the aquifer can be quickly consumed in the presence of assimilable dissolved and particulate organic carbon (DOC and POC). Depending on temperature and water composition, the depletion of dissolved oxygen might lead to anoxic conditions in sediments within short hydraulic retention times. The degradation of organic compounds can have a significant impact on redox-conditions in the subsoil. Furthermore, POC and DOC can be competitive substrates for OMP removal [12]. Still, DOC removal is a desired effect for BF and SAT.

Besides residual organic particles in treated wastewater, organic inputs into surface waters (e.g., leaves [13]) and phototrophic biomass production (e.g., algae) cause significant POC loads in BF and SAT. For example, Hoffmann and Gunkel [14] analyzed sediment cores of Lake Tegel and reported that $17-21 \%$ of the total sediment volume was filled with suspended or attached particulate organic matter.

The semi-closed water cycle in Berlin-Tegel is an example of de facto water reuse with BF and SAT as essential barriers [15]. Treated wastewater is partly discharged into Lake Tegel, which is an important water resource in the north-west of Berlin. Around 120 wells surrounding the shores of Lake Tegel are operated to withdraw bank filtrate that is further aerated and filtered before distribution. To cover seasonal demand peaks in summer, additional SAT is applied with Lake Tegel water.

The present study aimed at quantifying the long-term oxygen consumption in sediment cores taken from BF and SAT sites in Berlin. The cores represent varying amounts of organic carbon inventories. The oxygen consumption and its longevity, the DOC removal and release, and effects on the elimination of six indicator OMPs were investigated in long-term column experiments with a duration of 400 days [d].

\section{Materials and Methods}

\subsection{Sediment Cores}

Four cores taken from the Saatwinkel SAT site and two cores from the Lake Tegel BF site in Berlin were analyzed and investigated in long-term column experiments. Both sites have been previously studied $[2,5,16]$. The lake sediment cores L1 and L2 were taken from the sandy and non-vegetated riparian zone which is surrounded by trees at a water depth at approximately $0.2 \mathrm{~m}$. A column (acrylic glass, $65 \mathrm{~mm}$ inner diameter) was pushed into the sediment and sealed with a plug to remove the core. The SAT cores C1 and C2 originate from an unsaturated recharge basin built in the 1960s with an area of more than $8700 \mathrm{~m}^{2}$. After an operational cycle of about 3-4 months the recharge rate decreases and the clogging layer (approximately $10 \mathrm{~cm}$ of the upper sediment) is removed and replaced to re-establish the original hydraulic conductivity. The investigated recharge basin provides residuals of such a clogging layer at approximately $10-20 \mathrm{~cm}$ depth. It probably consists of residual algae and macrophytes, leaf litter inputs from surrounding trees, and lake water constituents and was partly replaced by washed sand in a cleaning campaign. To enable a comparison of the impacts of the remaining colmation layer, two cores from the deeper sand layer (S1 and S2) were analyzed as well. Figure 1a shows a vertical cross-section and presents schematically the origin of the SAT cores. 


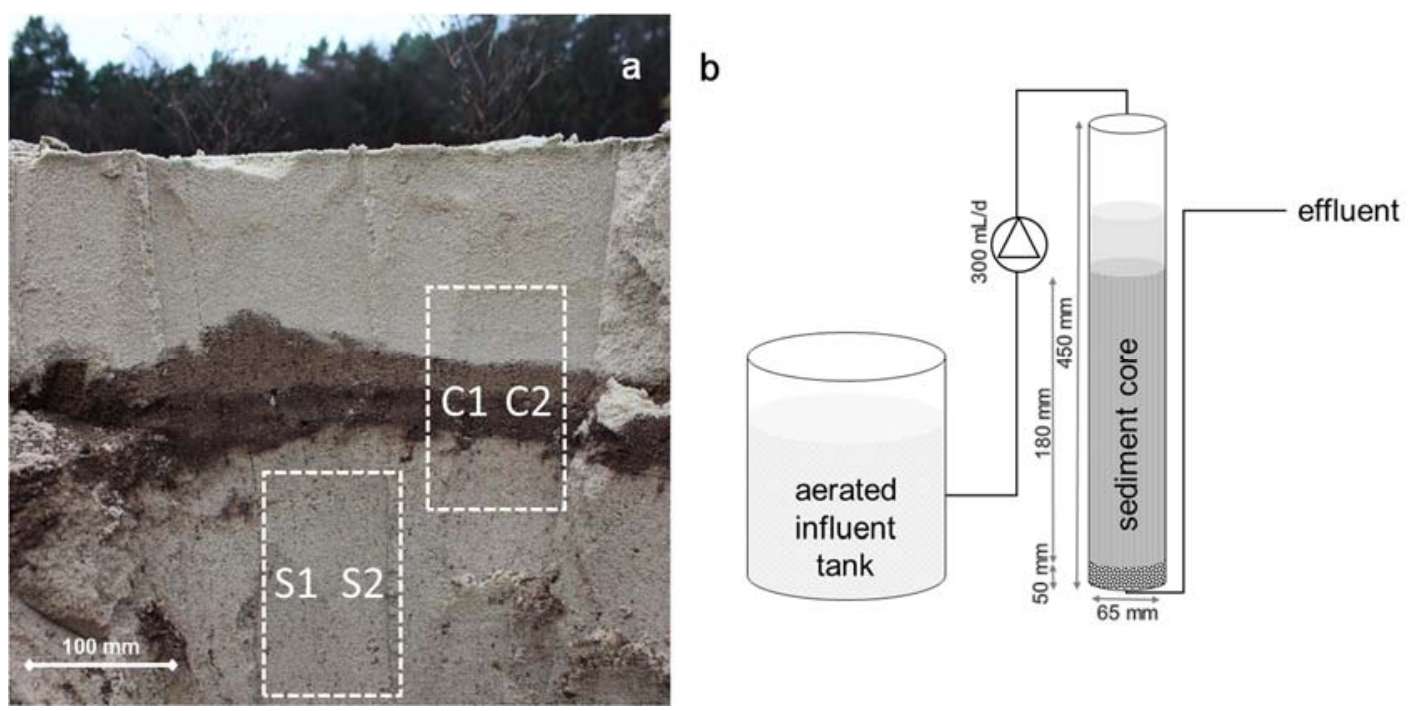

Figure 1. (a) Photograph of the profile in the soil aquifer treatment (SAT) basin with a replaced top layer, residuals of the colmation layer, and the underlying filter sand with schematic positions where cores C1, C2, S1, and S2 were withdrawn; (b) schematic illustration and approximate dimensions of the experimental setup.

\subsection{Column Experiments}

Non-chlorinated Berlin tap water originating from bank filtration was used as influent solution. Due to its origin with more than 50 days treatment during soil passage, the DOC of around $5 \mathrm{mg} / \mathrm{L}$ is hardly bio-degradable. Oxygen consumption can thus be attributed to the POC accumulated in the cores or to DOC adsorbed therein. Defined volumes of a stock solution containing $10 \mathrm{mg} / \mathrm{L}$ of sulfamethoxazole, benzotriazole, formylaminoantipyrine, diclofenac, gabapentin, and carbamazepine were added to the tap water to adjust influent OMP concentrations of $1 \mu \mathrm{g} / \mathrm{L}$. The influent solution was aerated by the use of mineral air stones and stirred to maintain oxic conditions. The influent was pumped into the open columns containing approximately $180 \mathrm{~mm}$ sediment core (ca. $0.6 \mathrm{~L}$ ) and a $50 \mathrm{~mm}$ supporting gravel layer. The columns were operated at $23 \pm 5^{\circ} \mathrm{C}$ with a downstream flow of $300 \mathrm{~mL} / \mathrm{d}$ and a corresponding infiltration rate of approximately $0.09 \mathrm{~m} / \mathrm{d}$, leading to a residence time of $14 \mathrm{~h}$ within the core. The water levels of the supernatants were adjusted by the position of the effluent outlet.

Samples were taken from the influent tank and by collecting the effluents in $1 \mathrm{~L}$ glass bottles (as $20 \mathrm{~h}$ composite samples) once a week in the initial phase and once in two weeks after day 100.

\subsection{Analyses}

The dissolved oxygen was measured with optodes (Presens, Germany) which were installed as flow through cells in the influent and effluent tubes. Except for iron and manganese analyses, all samples were vacuum-filtered with $0.45 \mu \mathrm{m}$ cellulose nitrate membrane filters (Satorius, Germany) prior to measurements. Iron and manganese were measured with atomic absorption spectrometry (AAS, flame 906AA, GBC-Scientific Equipment, Hampshire, IL, USA; graphite furnace Spectr AA-400, Varian, Palo Alto, CA, USA) in acidified and unfiltered samples.

The DOC was quantified with a TOC Cube analyzer (Elementar, Langenselbold, Germany) and further characterized with liquid chromatography and continuous organic carbon (LC-OCD) as well as UV detection (LC-UVD) [17,18]. The ultraviolet light absorption at $254 \mathrm{~nm}$ wavelength $\left(\mathrm{UV}_{254}\right)$ was measured with the spectral photometer Lamda 12 (Perkin Elmer, Rodgau, Germany). The selected OMPs were quantified by high performance liquid chromatography coupled with tandem 
mass spectrometry (HPLC-MS/MS) as described by Hellauer et al. [19] in detail with the respective quantification limits.

Additionally, sediment analyses were carried out. Sediment probes from the colmation layer and from the sand layer beneath were collected as $10 \mathrm{~kg}$ homogenized samples at different depths, whereas additional lake sediment cores where collected at the same sampling site as the cores L1 and L2. The two SAT sand samples as well as different layers of the lake sediment cores were analyzed for loss on ignition (EN, 2000). Analyses for carbon (DIN ISO 10694), nitrogen (DIN ISO 13878), and sulfur (DIN ISO 15178) contents were carried out with a CNS analyzer Vario EL III (Elementar, Langenselbold, Germany). Iron and manganese contents in the sediments were determined by suspending $5 \mathrm{~g}$ of the dried sediments $\left(50^{\circ} \mathrm{C}\right)$ in $50 \mathrm{~mL}$ deionized water acidified with $0.5 \mathrm{~mL}$ hydrochloric acid $(32 \%)$. After $95 \mathrm{~h}$ shaking, the probes were filtrated with $0.45 \mu \mathrm{m}$ cellulose nitrate membrane filters and analyzed with AAS.

\section{Results and Discussions}

\subsection{Sediment Analyses}

The investigated cores contained different amounts of organic carbon and inorganic inventories, as listed in Table 1 . The sample originating from the SAT basin relating to $\mathrm{C} 1$ and $\mathrm{C} 2$ showed a loss on ignition of only $0.12 \%$ by weight, which is in accordance with the low carbon concentration of only $0.04 \%$ by mass. Thus, the values reflect a technical sand layer with minor carbon inventories. The sediment probes from the residuals of the colmation layer incorporated in C3 and C4 revealed a loss on ignition of $0.63 \%$ by weight and a carbon concentration of $0.29 \%$ by mass, and thus had significantly more accumulated organic carbon compared to the subjacent sand layer. The loss on ignition and the detected carbon of lake sediment probes presented much larger organic carbon inventories compared to sand probes from the technical SAT system. However, the analyzed lake sediments showed high variations of carbon contents and chemical compositions due to randomly and locally varying immobilization and inputs of aquatic (e.g., algae, dead organisms) and terrestrial (e.g., leaves, branches, litter) organic material.

Table 1. Loss on ignition and elemental concentrations analyzed in cores or samples additionally taken at the respective sites; six adjacent bank filtration $(\mathrm{BF})$ cores were analyzed with vertical subsamples (14 in total) to cover the great heterogeneity.

\begin{tabular}{cccc}
\hline Parameter & SAT Sand & SAT Sand with Colmation & BF Cores \\
\hline Loss on ignition [\%] & 0.12 & 0.63 & $5.7 \pm 7.1$ \\
Iron [g/kg] & 0.35 & 1.23 & $0.19 \pm 0.08$ \\
Manganese [g/kg] & 0.05 & 0.39 & - \\
Carbon [\%] & 0.04 & 0.29 & $3.6 \pm 4.7$ \\
Nitrogen [\%] & 0.01 & 0.02 & $0.26 \pm 0.36$ \\
C/N [ ] & 5.6 & 14.9 & $16.5 \pm 2.5$ \\
\hline
\end{tabular}

As expected, the nitrogen contents increased with increasing accumulated carbon, since it is bound in organic substrate. The carbon to nitrogen $(\mathrm{C} / \mathrm{N})$ ratio can indicate the origin and degradation state of organic material. For aquatic phyto- and zooplankton containing a larger amount of nitrogen rich proteins, $\mathrm{C} / \mathrm{N}$ ratios of 5-6 were reported, while the ratio for terrestrial plants ranges from 15 to $40[20,21]$. During degradation, the ratio increases for aquatic organic material, while it decreases for terrestrial material [22]. The analyzed samples containing residuals of the colmation layer showed a $\mathrm{C} / \mathrm{N}$ ratio of approximately 15 , thereby indicating the presence of more persistent terrestrial organic matter originating from plants surrounding the SAT basin or of degraded plankton from the infiltrated surface water or a combination thereof. The bank core revealed a similar $\mathrm{C} / \mathrm{N}$ ratio at much higher carbon and nitrogen contents, indicating a comparable state of degradation for the accumulated POC. 
The SAT with residuals of the colmation layer showed a high concentration of $1.23 \mathrm{~g} / \mathrm{kg}$ accumulated iron and elevated manganese inventories compared to subjacent SAT sand. These concentrations indicate that iron and manganese precipitates were accumulated in addition to organic material during the colmation process. The iron probably stems from the infiltrated lake water. The low iron contents in the analyzed lake sediments indicate the absence of poorly soluble iron sulfides that often occur in anaerobic sediments due to their very low solubility. Thus, the redox potential was not sufficiently low for sulfate reduction but the associated mobilization of iron as ferrous iron.

\subsection{Oxygen Consumption}

Although the cores were only approximately $180 \mathrm{~mm}$ in height, all parallel cores showed a high or even complete oxygen consumption during the first 150 days, as displayed in Figure 2. The accumulated POC even in the lower sand layer (cores S1 and S2) was capable of influencing the redox conditions substantially, despite the low carbon content of only $0.04 \%$. The cleaning of the SAT basin by removing the top colmation layer therefore was not sufficient to recover the oxygen supply to lower layers completely. From day 200 onwards, the oxygen concentrations in the SAT column effluents increased significantly. The cores C1 and C2 with residuals of the colmation layer revealed higher oxygen consumptions during the complete experiment duration compared to the parallel cores S1 and S2 containing the subjacent SAT sand. The higher carbon content in the colmation layer (as given in Table 1) provides a reasonable explanation. Thus, the accumulation of POC in the SAT basin affects the redox-conditions during treatment.

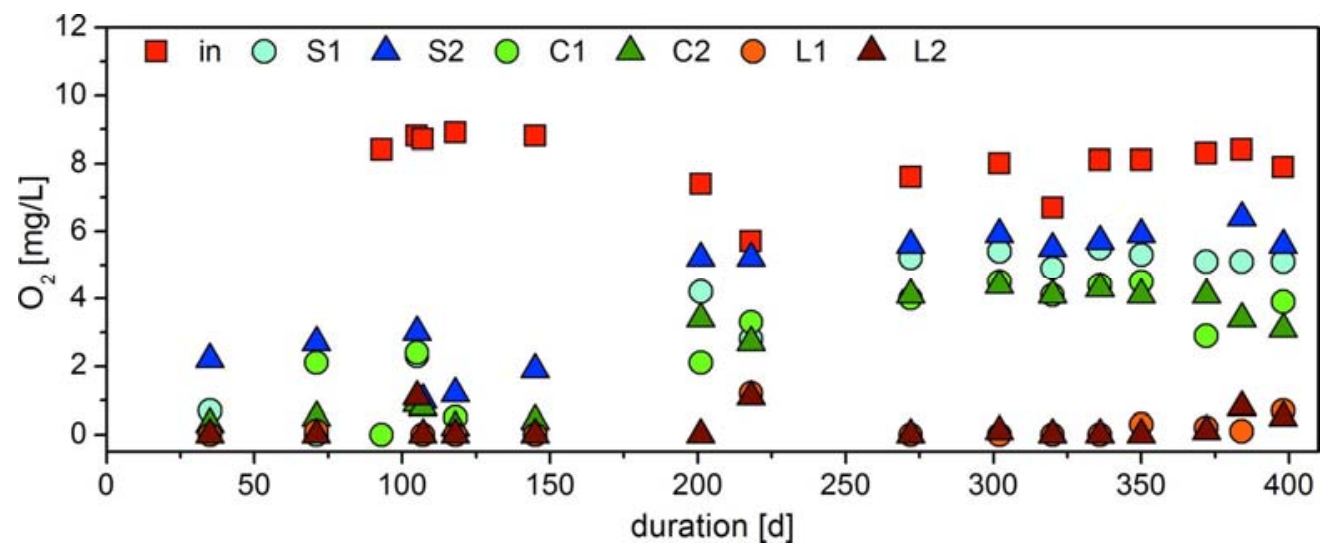

Figure 2. Dissolved oxygen concentrations of the influent tap water and of the effluents of the cores.

The effluents of columns L1 and L2 showed oxygen concentrations below $1 \mathrm{mg} / \mathrm{L}$ throughout 400 days, exceeding the duration of an annual cycle. The continuous supply of new POC by, for example, autumnal leaf litter inputs and sedimentation of dead phototrophic organisms is expected to further increase the accumulation of oxygen consuming matter. Approximately $1.1 \mathrm{~g}$ oxygen (cumulative) were consumed over 400 days in each lake sediment column. Assuming a specific oxygen demand of $2.7 \mathrm{~g}$ molecular oxygen for the complete mineralization of $1 \mathrm{~g}$ organic carbon with an average oxidation level of $\pm 0\left(\mathrm{M}_{\mathrm{O} 2} / \mathrm{M}_{\mathrm{C}}\right), 0.4 \mathrm{~g}$ carbon were degraded. This theoretical amount represents less than $2 \%$ of the $28 \mathrm{~g}$ provided organic carbon in the form of POC and DOC. A similar observation was reported in a previous study, where no limitation of particulate organic matter for long-term aerobic respiration was observed in sediment column experiments [23]. Since oxygen is consumed within several decimeters in the column experiments simulating the first decimeters of bank filtration, the bank filtration path after several decimeters at the investigated site of Lake Tegel is not likely to provide oxic conditions and thus certain compounds might require additional treatment, for example, by aeration with subsequent re-infiltration [19]. 
Since the influent tap water contained only DOC $(5.04 \pm 0.26 \mathrm{mg} / \mathrm{L})$, which is not biodegradable, the observed oxygen consumption likely resulted from the degradation of accumulated POC or DOC in the sediments. In this way, even low concentrations of POC in the upper sediment layers could lead to a fast change of redox conditions within several decimeters. The long-term oxygen consumptions revealed a relation with the differing amounts of accumulated organic carbon measured as loss on ignition and carbon contents in sediment analyses presented in Table 1.

\subsection{Iron and Mangenese}

Even though sediment analyses revealed increased iron and manganese inventories for the residual colmation layer, no significant amounts of iron and manganese were mobilized and released from the SAT cores C1 and C2, since oxidants stronger than ferric iron (e.g., oxygen, nitrate) were still available. Therefore, the mobilization of both ions reveals a redox potential between nitrate and sulfur reducing conditions at neutral $\mathrm{pH}$ and can be an indicator for anoxic degradation pathways. The releases of dissolved iron and manganese from the different sediment cores are presented in Figure 3.
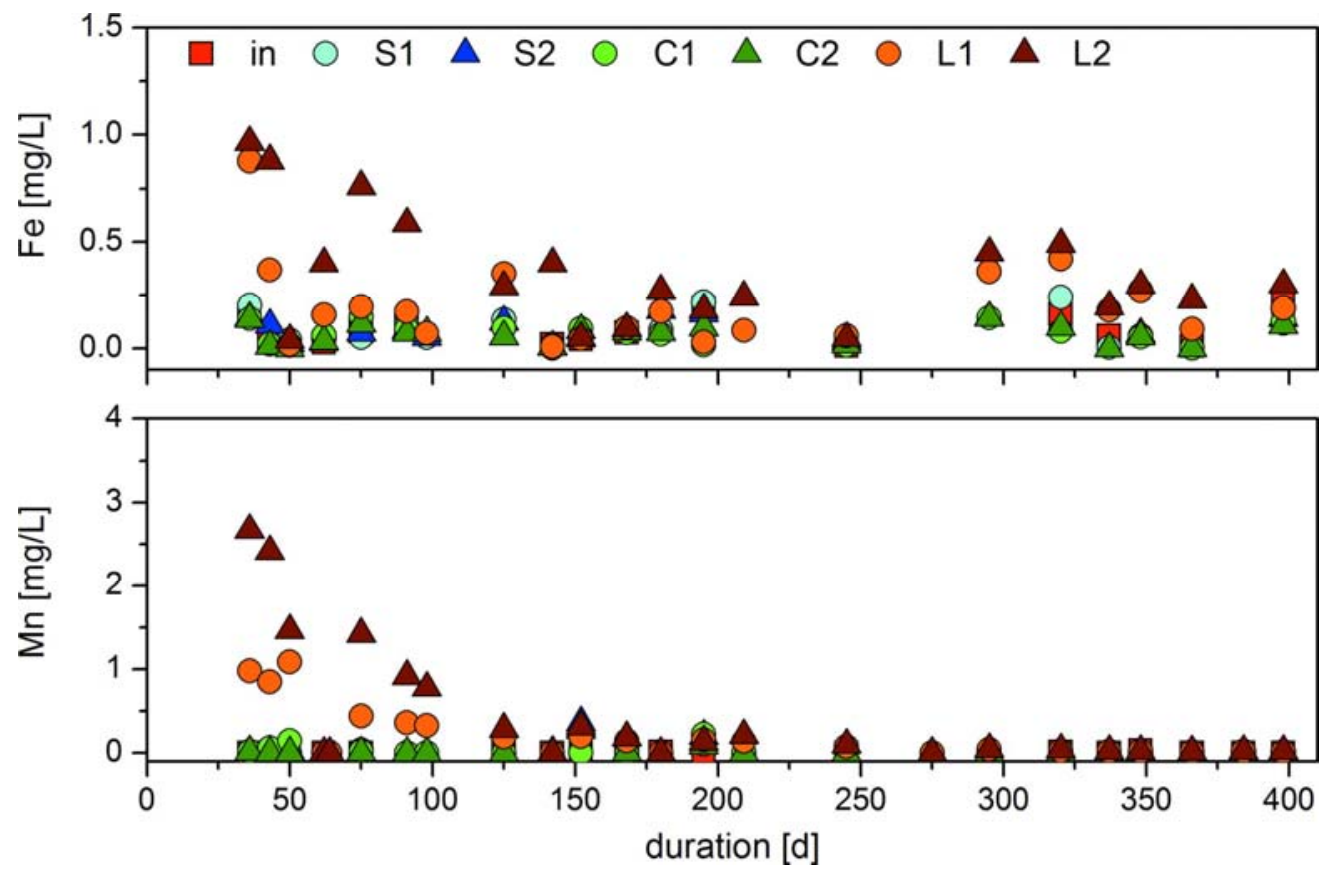

Figure 3. Iron and manganese concentrations in the influent tap water and in the effluents of the SAT and BF cores.

In the effluents of L1, and especially of L2, increased iron concentrations of up to $0.9 \mathrm{mg} / \mathrm{L}$ and manganese concentrations of up to $1.5 \mathrm{mg} / \mathrm{L}$ were measured during the first 100 days due to reductive dissolution of precipitated iron and manganese, respectively. The approximate amounts of released iron and manganese from L1 (approximately $30 \mathrm{mg}$ Fe and $14 \mathrm{mg} \mathrm{Mn}$ ) and L2 (approximately $40 \mathrm{mg} \mathrm{Fe}$ and $25 \mathrm{mg} \mathrm{Mn}$ ) do not necessarily reflect the extent of reducing conditions due to potentially differing accumulated reservoirs.

After day 100, no significant further releases were observed. Thus, iron and manganese inventories might have been washed out, or the intrusion of oxygen increased the redox potential and might have prevented a further reduction and release of iron and manganese. 


\subsection{Removal of Bulk Organic Parameters}

Significant differences in DOC releases were observed between SAT and bank filtration sediments, as presented in Figure 4. Increased DOC concentrations were observed in the effluents of the lake sediments probably due to degradation of accumulated POC to DOC. The release of DOC might also be connected to the reductive dissolution of iron minerals that are known to adsorb natural organic matter [24]. The $\mathrm{UV}_{254}$ is related with the DOC release, indicating a washout of substances that contain aromatic structures and double bonds.
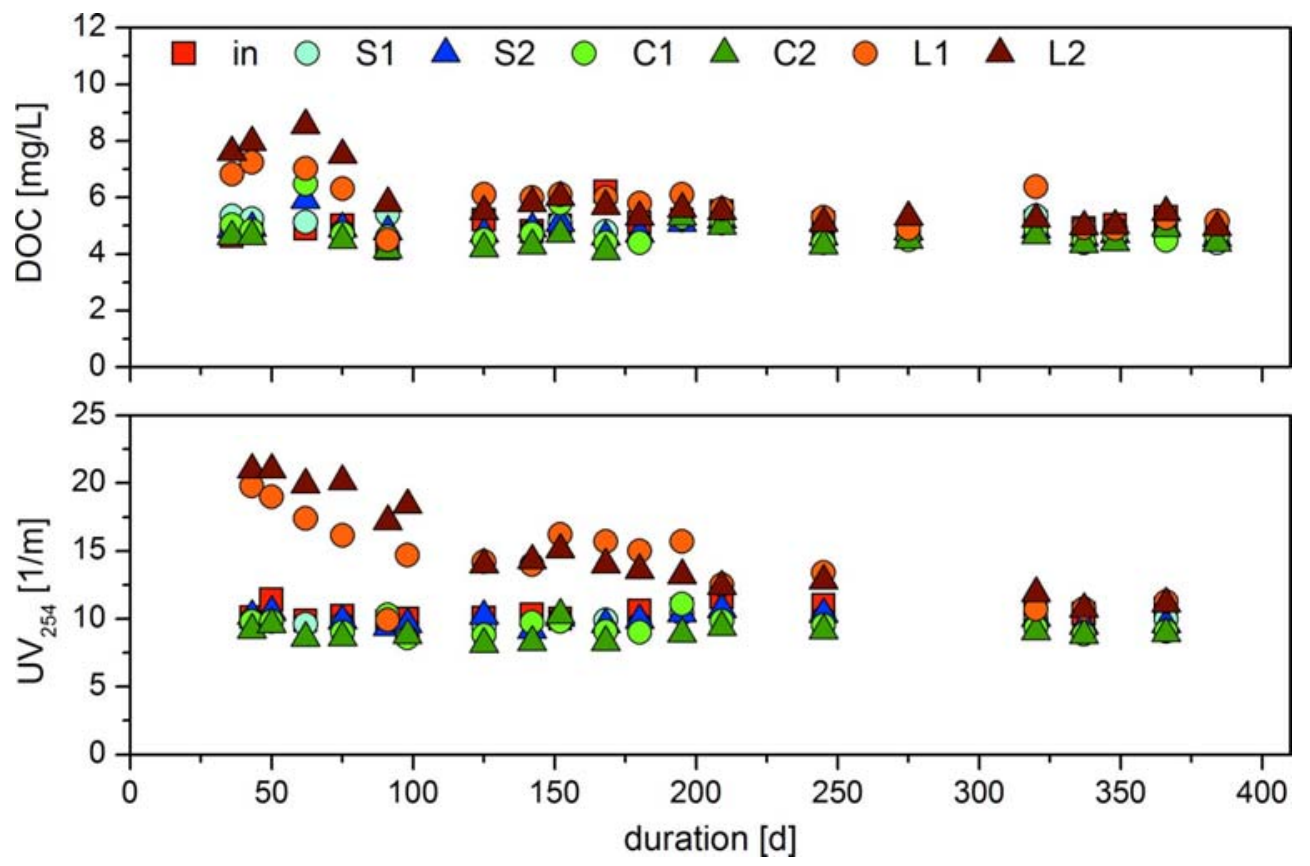

Figure 4. Dissolved organic carbon (DOC) concentrations and ultraviolet light absorption at $254 \mathrm{~nm}$ wavelength $\left(\mathrm{UV}_{254}\right)$ in influent and column effluents.

The qualitative LC-OCD and LC-UVD chromatograms of samples taken after 76 days of operation (Figure 5) revealed a peak at a retention time of 40-50 $\mathrm{min}$, thereby verifying the release of humic substances from the lake sediment cores. Additionally, a slight peak at a retention time of 30-40 min usually attributed to bio-polymers [17] occurred in the effluents of columns L1 and L2. Interestingly, the released humic substances contributed more to the overall $\mathrm{UV}_{254}$ increase than to the DOC, as the LC-UVD chromatograms showed a greater increase in peak height (and peak area, respectively). The observed release from organic depositions in lake sediments might be a possible source for humic substances in bank filtrate and groundwater. Seasonal inputs of fresh POC probably increase the DOC release again. Artificially fragmented leaves have been reported to be a source of DOC leaching [13]. However, degradation of non-destructed organic matter probably lasts longer.

Although the potential for oxic degradation of DOC was described in previous column studies (e.g., [11,19]) and field studies [2], only minor DOC removal is observed in this study. Since the local tap water used as influent originates from the bank filtration site after more than 50 days of subsurface treatment, the DOC concentrations of $4-5 \mathrm{mg} / \mathrm{L}$ are already low and no further oxic conversion is expected within the comparably short residence time in the cores.

Against the expectations, the LC-OCD and LC-UVD chromatograms in Figure 5 reveal a slight retention of mainly humic substances and low molecular weight acids in the SAT cores. The capability of SAT for DOC removal has been reported before. Amy and Drewes [25] found in a SAT field study a preferential biological removal of high molecular-weight non-humic components (e.g., proteins, polysaccharides), while humic substances were only removed over longer filtration times. 


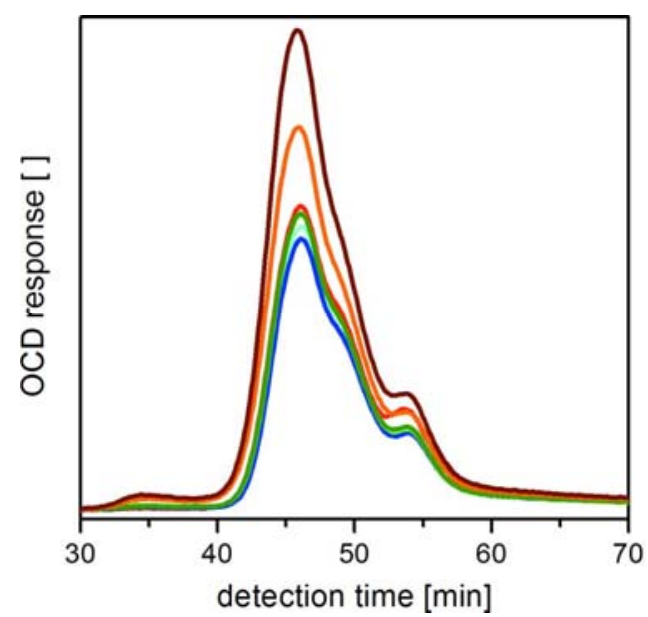

(a)

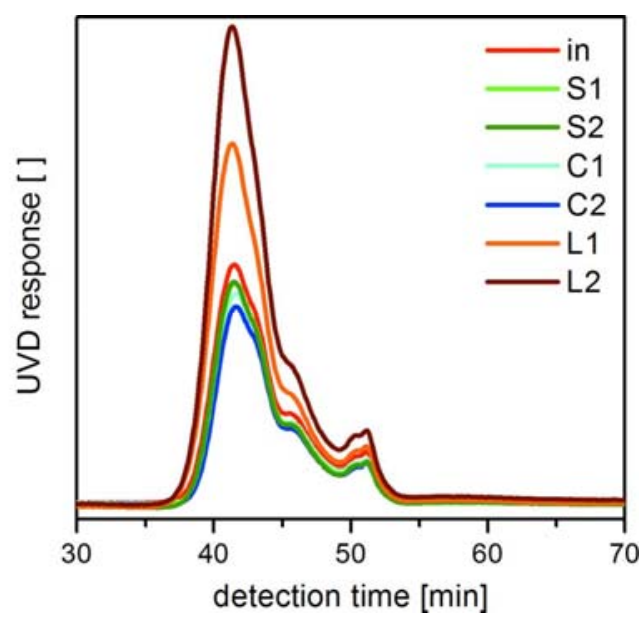

(b)

Figure 5. Liquid chromatography and continuous organic carbon (LC-OCD) (a) and liquid chromatography with UV detection (LC-UVD) (b) chromatograms of the influent tap water and the core effluents after 76 days of operation.

In addition to biodegradation, the humic substances might also adsorb onto iron oxides or other adsorbing core constituents until the adsorption capacity for humic substances was depleted with ongoing operation. Thus, DOC mineralization or adsorption overcompensated DOC releases from accumulated POC in the SAT cores in accordance to other studies (e.g., [19,26]). Studies reveal that low amounts of primary substrate (e.g., POC and DOC) can improve the removal of moderately degradable OMPs [27]. Alidina et al. [28] observed a higher removal due to a higher microbial diversity when using a humic acid as a refractory substrate source. In this study, a higher amount of accumulated carbon was probably used as primary substrate source in lake sediments. Therefore, the POC and mobilized DOC from lake sediments might compete as a substrate and additionally inhibit further specialization of microorganisms for OMP degradation.

\subsection{OMP Eliminations}

Sulfamethoxazole was almost completely eliminated in all cores during the long-term experiments independent of the effluent oxygen concentrations and of released iron or manganese, which indicated reducing conditions (Figure 6). The efficient elimination of sulfamethoxazole is in accordance with other studies that reported sulfamethoxazole to be degraded under both oxic and anoxic conditions [29]. Accordingly, Jekel et al. [30] selected sulfamethoxazole as a process indicator that is well removed in subsurface treatments. The results of this study show that even very short distances and residence times are sufficient for the elimination of sulfamethoxazole.

Formylaminoantipyrine was almost eliminated by $85 \%$ in SAT cores. A decreased removal was observed in the lake sediment core L1. Concentrations of the parameters discussed above do not provide a clear explanation for the lower efficiency of column L1 compared to column L2. Although L2 showed stronger reducing conditions with regard to iron and manganese releases and oxygen consumption, formylaminoantipyrine was removed to a greater extent in L2. Differences in the microbial composition might be responsible for the observed differences. 

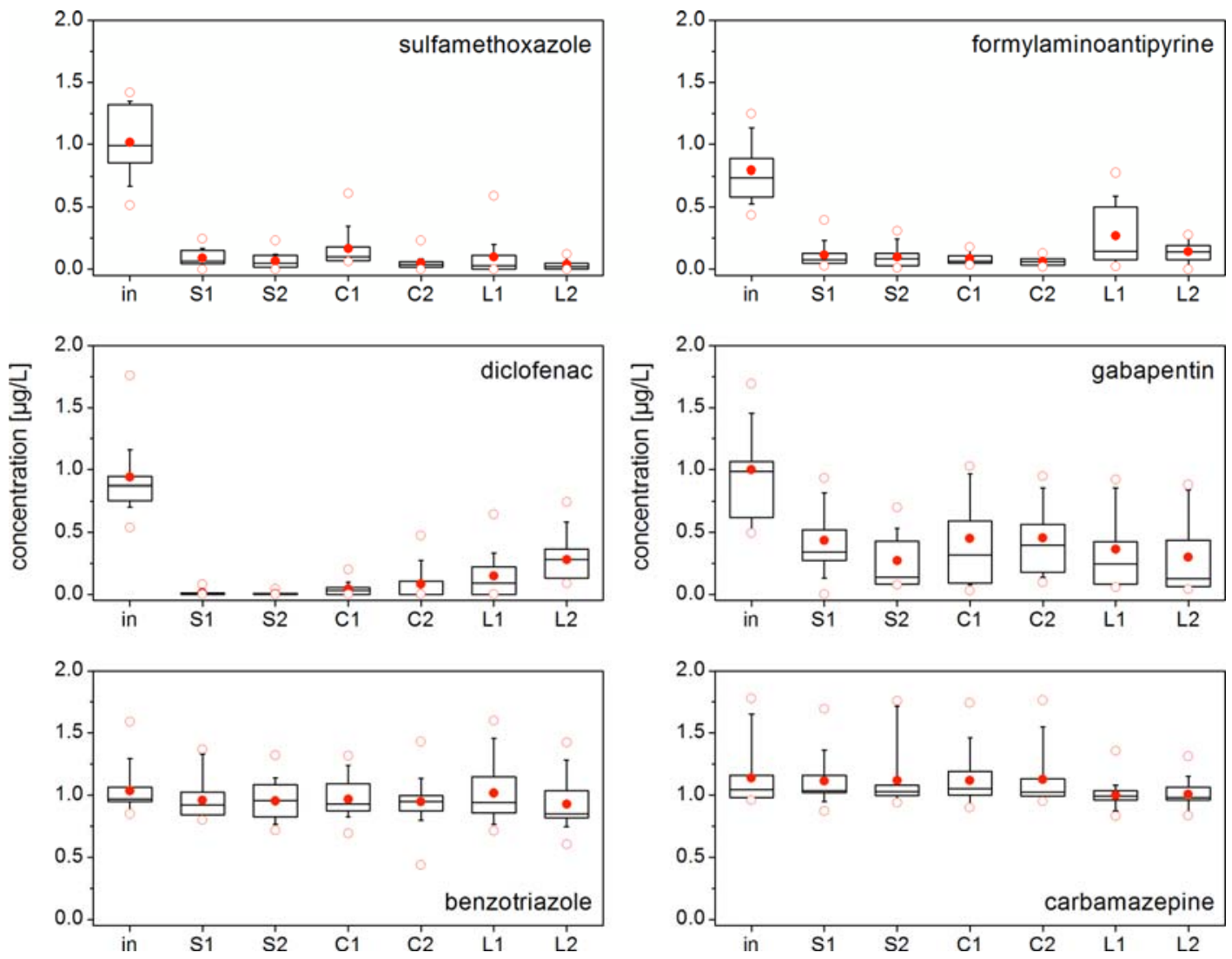

Figure 6. Concentrations of sulfamethoxazole, formylaminoantipyrine, diclofenac, gabapentin, benzotriazole, and carbamazepine adjusted in the influent tap water and in the respective effluents. The boxes represent the 25th and the 75th percentiles as well as the median value, with whiskers indicating the lower (10th percentile) and the upper (90th percentile) adjacent values. The empty dots represent the outside values and the red dots the mean values $(n \geq 11)$.

More than $90 \%$ of the diclofenac concentration was eliminated in SAT cores, with a slightly lower removal in the SAT core C2. Higher effluent concentrations of diclofenac were also observed in the lake sediment cores L1, and especially L2, indicating an effect of the higher organic carbon inventories and the almost complete oxygen consumption. Diclofenac was probably only exposed for a short time to oxic conditions due to the rapid consumption of oxygen. Another explanation could be the high amounts of accumulated POC and DOC mobilization, which were degraded preferably by less specified microorganisms and caused a decreased removal of diclofenac.

The removal of gabapentin in soils and sediments is hardly studied but can be enhanced under oxic conditions in soil column systems [19]. In the experiments, gabapentin showed a removal in all investigated sediments which cannot be linked to the organic carbon inventories and the observed redox conditions in the sediment cores. It is possible that variations of the influent concentration might have disturbed slowly adapting microorganisms, causing increased effluent concentrations of gabapentin. It has to be considered that the observed eliminations of the previously discussed OMPs do not necessarily reflect the biodegradability, since metabolites were not analyzed and sorption effects could not be considered.

Heterogeneous behaviors have been reported for benzotriazole, with removals ranging from 75-90\% in bank filtration [6], and only poor removals in column experiments with lake sediments [11]. In the present study, no remarkable eliminations of benzotriazole were observed in the different cores. It is probable that the retention times were too short to achieve substantial removals. 
Although a degradation of carbamazepine was observed in the presence of high POC contents [31] and iron reducing conditions [5], carbamazepine was often found to be persistent $[11,32,33$ ]. Accordingly, carbamazepine was proposed as an indicator compound for anthropogenic influences in the water cycles [30]. No carbamazepine removal was observed in the different sediment cores.

\section{Conclusions}

Sediments in SAT and BF systems can contain significantly differing amounts of organic carbon affecting the redox-conditions due to oxic degradation. Especially the accumulated POC in the uppermost BF layer can maintain anoxic conditions over more than 400 days. High concentrations of DOC were released from BF cores during the initial phase of 100 days, most probably due to biological conversion and dissolution of POC. Even if the quality of the overlying waterbody achieves oligotrophic conditions, organic rich sediments might impede the removal of DOC and redox-sensitive OMPs like diclofenac and formylaminoantipyrine.

In contrast, the increased oxygen consumption due to the residual colmation layer did not affect the DOC release and had no effect on OMP removal. SAT cores showed an almost complete elimination of sulfamethoxazole, formylaminoantipyrine, and diclofenac within the limited core length of approximately $180 \mathrm{~mm}$, since oxic conditions were retained. Benzotriazole and carbamazepine were neither removed in the SAT cores nor in the BF material.

Acknowledgments: We thank the Berliner Wasserbetriebe (BWB) for funding the project Uferfiltration and the project partners for valuable discussions. We wish to thank Theresa C. Sichler and Yuki Sorgler for laboratory support.

Author Contributions: M. Jekel and A. S. Ruhl conceived and designed the experiments; J. Filter and A. S. Ruhl performed the experiments; J. Filter and A. S. Ruhl analyzed the data; M. Jekel contributed reagents and materials; J. Filter and A. S. Ruhl wrote the paper and M. Jekel corrected and improved it; M. Jekel and A. S. Ruhl supervised this study.

Conflicts of Interest: The authors declare no conflict of interest. The founding sponsors had no role in the design of the study; in the collection, analyses, or interpretation of data; in the writing of the manuscript, and in the decision to publish the results.

\section{References}

1. Tufenkji, N.; Ryan, J.N.; Elimelech, M. The promise of bank filtration. Environ. Sci. Technol. 2002, 36, 422-428. [CrossRef]

2. Grünheid, S.; Amy, G.; Jekel, M. Removal of bulk dissolved organic carbon (DOC) and trace organic compounds by bank filtration and artificial recharge. Water Res. 2005, 39, 3219-3228. [CrossRef] [PubMed]

3. Massmann, G.; Heberer, T.; Grützmacher, G.; Dünnbier, U.; Knappe, A.; Meyer, H.; Mechlinski, A.; Pekdeger, A. Drinking-water production in urban environments bank filtration in Berlin. Grundwasser 2007, 12, 232-245. [CrossRef]

4. Schmidt, C.K.; Lange, F.T.; Brauch, H.J. Characteristics and evaluation of natural attenuation processes for organic micropollutant removal during riverbank filtration. Water Sci. Technol. Water Supply 2007, 7, 1-7. [CrossRef]

5. Wiese, B.; Massmann, G.; Jekel, M.; Heberer, T.; Dünnbier, U.; Orlikowski, D.; Grützmacher, G. Removal kinetics of organic compounds and sum parameters under field conditions for managed aquifer recharge. Water Res. 2011, 45, 4939-4950. [CrossRef] [PubMed]

6. Reemtsma, T.; Miehe, U.; Duennbier, U.; Jekel, M. Polar pollutants in municipal wastewater and the water cycle: Occurrence and removal of benzotriazoles. Water Res. 2010, 44, 596-604. [CrossRef] [PubMed]

7. Heberer, T.; Mechlinski, A.; Fanck, B.; Knappe, A.; Massmann, G.; Pekdeger, A.; Fritz, B. Field studies on the fate and transport of pharmaceutical residues in bank filtration. Ground Water Monit. Remediat. 2004, 24, 70-77. [CrossRef]

8. Scheurer, M.; Brauch, H.J.; Lange, F.T. Analysis and occurrence of seven artificial sweeteners in German waste water and surface water and in soil aquifer treatment (SAT). Anal. Bioanal. Chem. 2009, 394, 1585-1594. [CrossRef] [PubMed] 
9. Drewes, J.E.; Heberer, T.; Rauch, T.; Reddersen, K. Fate of pharmaceuticals during ground water recharge. Ground Water Monit. Remediat. 2003, 23, 64-72. [CrossRef]

10. Bertelkamp, C.; Reungoat, J.; Cornelissen, E.R.; Singhal, N.; Reynisson, J.; Cabo, A.J.; van der Hoek, J.P.; Verliefde, A.R.D. Sorption and biodegradation of organic micropollutants during river bank filtration: A laboratory column study. Water Res. 2014, 52, 231-241. [CrossRef] [PubMed]

11. Burke, V.; Greskowiak, J.; Asmuss, T.; Bremermann, R.; Taute, T.; Massmann, G. Temperature dependent redox zonation and attenuation of wastewater-derived organic micropollutants in the hyporheic zone. Sci. Total Environ. 2014, 482, 53-61. [CrossRef] [PubMed]

12. Drewes, J.E.; Li, D.; Regnery, J.; Alidina, M.; Wing, A.; Hoppe-Jones, C. Tuning the performance of a natural treatment process using metagenomics for improved trace organic chemical attenuation. Water Sci. Technol. 2014, 69, 628-633. [CrossRef] [PubMed]

13. Bayarsaikhan, U.; Ruhl, A.S.; Jekel, M. Characterization and quantification of dissolved organic carbon releases from suspended and sedimented leaf fragments and of residual particulate organic matter. Sci. Total Environ. 2016, 571, 269-274. [CrossRef] [PubMed]

14. Hoffmann, A.; Gunkel, G. Bank filtration in the sandy littoral zone of lake tegel (Berlin): Structure and dynamics of the biological active filter zone and clogging processes. Limnologica 2011, 41, 10-19. [CrossRef]

15. Jekel, M.; Ruhl, A.S.; Meinel, F.; Zietzschmann, F.; Lima, S.; Baur, N.; Wenzel, M.; Gnirß, R.; Sperlich, A.; Dünnbier, U.; et al. Anthropogenic organic micro-pollutants and pathogens in the urban water cycle: Assessment, barriers and risk communication (ASKURIS). Environ. Sci. Eur. 2013, 25, 20. [CrossRef]

16. Greskowiak, J.; Prommer, H.; Massmann, G.; Johnston, C.D.; Nützmann, G.; Pekdeger, A. The impact of variably saturated conditions on hydrogeochemical changes during artificial recharge of groundwater. Appl. Geochem. 2005, 20, 1409-1426. [CrossRef]

17. Haberkamp, J.; Ruhl, A.S.; Ernst, M.; Jekel, M. Impact of coagulation and adsorption on doc fractions of secondary effluent and resulting fouling behaviour in ultrafiltration. Water Res. 2007, 41, 3794-3802. [CrossRef] [PubMed]

18. Huber, S.A.; Balz, A.; Abert, M.; Pronk, W. Characterisation of aquatic humic and non-humic matter with size-exclusion chromatography - organic carbon detection - organic nitrogen detection (LC-OCD-OND). Water Res. 2011, 45, 879-885. [CrossRef] [PubMed]

19. Hellauer, K.; Mergel, D.; Ruhl, A.S.; Filter, J.; Hübner, U.; Jekel, M.; Drewes, J.E. Advancing sequential managed aquifer recharge technology (SMART) using different intermediate oxidation processes. Water Pract. Technol. 2017, 9, 221. [CrossRef]

20. Bordovskiy, O.K. Accumulation of organic matter in bottom sediments. Marine Geology 1965, 3, 33-82. [CrossRef]

21. Hedges, J.I.; Clark, W.A.; Quay, P.D.; Richey, J.E.; Devol, A.H.; Santos, U.d.M. Compositions and fluxes of particulate organic material in the amazon river. Limnol. Oceanogr. 1986, 31, 717-738. [CrossRef]

22. Meyers, P.A.; Leenheer, M.J.; Eaoie, B.; Maule, S. Organic geochemistry of suspended and settling particulate matter in lake michigan. Geochim. Cosmochim. Acta 1984, 48, 443-452. [CrossRef]

23. Von Rohr, M.R.; Hering, J.G.; Kohler, H.P.E.; von Gunten, U. Column studies to assess the effects of climate variables on redox processes during riverbank filtration. Water Res. 2014, 61, 263-275. [CrossRef] [PubMed]

24. Genz, A.; Baumgarten, B.; Goernitz, M.; Jekel, M. Nom removal by adsorption onto granular ferric hydroxide: Equilibrium, kinetics, filter and regeneration studies. Water Res. 2008, 42, 238-248. [CrossRef] [PubMed]

25. Amy, G.; Drewes, J. Soil aquifer treatment (SAT) as a natural and sustainable wastewater reclamation/reuse technology: Fate of wastewater effluent organic matter (EfOM) and trace organic compounds. Environ. Monit. Assess. 2007, 129, 19-26. [CrossRef] [PubMed]

26. Gruenheid, S.; Huebner, U.; Jekel, M. Impact of temperature on biodegradation of bulk and trace organics during soil passage in an indirect reuse system. Water Sci. Technol. 2008, 57, 987-994. [CrossRef] [PubMed]

27. Rauch-Williams, T.; Hoppe-Jones, C.; Drewes, J.E. The role of organic matter in the removal of emerging trace organic chemicals during managed aquifer recharge. Water Res. 2010, 44, 449-460. [CrossRef] [PubMed]

28. Alidina, M.; Li, D.; Ouf, M.; Drewes, J.E. Role of primary substrate composition and concentration on attenuation of trace organic chemicals in managed aquifer recharge systems. J. Environ. Manag. 2014, 144, 58-66. [CrossRef] [PubMed] 
29. Baumgarten, B.; Jahrig, J.; Reemtsma, T.; Jekel, M. Long term laboratory column experiments to simulate bank filtration: Factors controlling removal of sulfamethoxazole. Water Res. 2011, 45, 211-220. [CrossRef] [PubMed]

30. Jekel, M.; Dott, W.; Bergmann, A.; Duennbier, U.; Gnirss, R.; Haist-Gulde, B.; Hamscher, G.; Letzel, M.; Licha, T.; Lyko, S.; et al. Selection of organic process and source indicator substances for the anthropogenically influenced water cycle. Chemosphere 2015, 125, 155-167. [CrossRef] [PubMed]

31. Banzhaf, S.; Nödler, K.; Licha, T.; Krein, A.; Scheytt, T. Redox-sensitivity and mobility of selected pharmaceutical compounds in a low flow column experiment. Sci. Total Environ. 2012, 438, 113-121. [CrossRef] [PubMed]

32. Bertelkamp, C.; Verliefde, A.R.D.; Schoutteten, K.; Vanhaecke, L.; Bussche, J.; Singhal, N.; van der Hoek, J.P. The effect of redox conditions and adaptation time on organic micropollutant removal during river bank filtration: A laboratory-scale column study. Sci. Total Environ. 2016, 544, 309-318. [CrossRef] [PubMed]

33. König, A.; Weidauer, C.; Seiwert, B.; Reemtsma, T.; Unger, T.; Jekel, M. Reductive transformation of carbamazepine by abiotic and biotic processes. Water Res. 2016, 101, 272-280. [CrossRef] [PubMed]

(C) 2017 by the authors. Licensee MDPI, Basel, Switzerland. This article is an open access article distributed under the terms and conditions of the Creative Commons Attribution (CC BY) license (http:/ / creativecommons.org/licenses/by/4.0/). 